\title{
Toxic metals in maternal blood, cord blood and meconium of newborn infants in Pakistan
}

\author{
Sina Aziz', Shakil Ahmed ${ }^{2}$, Saadiya Aziz Karim ${ }^{3}$, Subhana Tayyab ${ }^{7}$ and Anisa Shirazi ${ }^{2}$
}

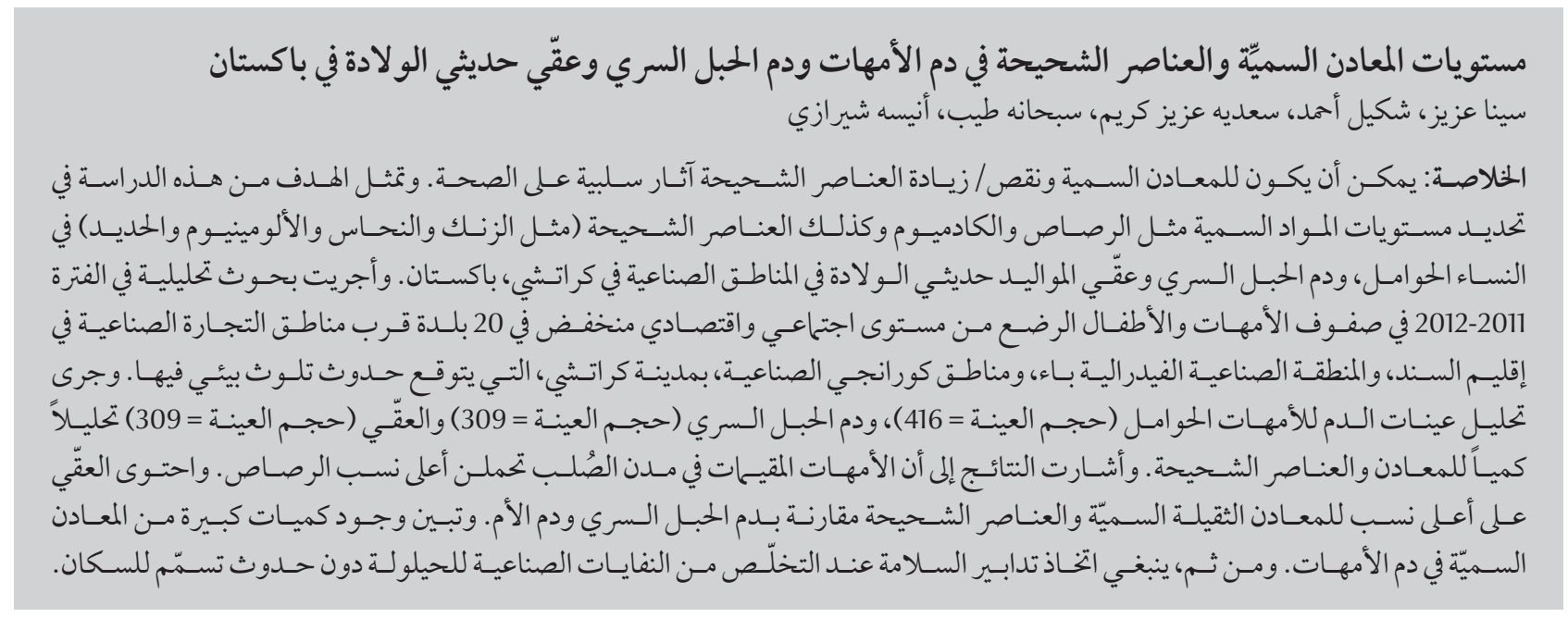

ABSTRACT Toxic metals and deficiency/excess of trace elements can have adverse effects on health. The aim of this study was to quantify toxic metals lead, cadmium and trace elements zinc, copper, aluminium (Al) and Iron (Fe) levels in pregnant women, cord blood and meconium of new-born infants from industrial zones of Karachi, Pakistan. Analytical research was performed from 2011-2012 in low socio-economic pregnant mothers and newborn infants from 20 towns near Sindh Industrial Trading Estates, Federal B industrial area and Korangi industrial areas, Karachi, where environmental pollution was anticipated. Blood samples of pregnant women $(n=416)$, cord blood $(n=309)$ and meconium $(n=309)$ were analyzed quantitatively for metals and trace elements. Results indicated that mothers residing in steel towns were found to have the highest levels of lead. Meconium contained high levels of toxic heavy metals and trace elements compared to cord blood and maternal blood. Maternal blood toxic metals were present in high quantities. Therefore, safety measures should be taken when industrial waste is disposed of in order to prevent population contamination.

Taux de métaux toxiques et d'éléments traces dans le sang maternel, le sang cordonal et le méconium des nouveau-nés au Pakistan

RÉSUMÉ Les métaux toxiques et la carence ou l'excès en éléments traces peuvent avoir des effets nocifs sur la santé. La présente étude avait pour objectif de quantifier les taux de métaux toxiques (plomb, cadmium) et d'éléments traces (zinc, cuivre, aluminium et fer) contenus dans le sang des femmes enceintes, le sang cordonal, et le méconium des nouveau-nés dans des zones industrielles de Karachi (Pakistan). Une recherche analytique a été menée en 2011 et 2012 sur des femmes enceintes et des nouveau-nés au niveau socioéconomique faible dans vingt villes proches des zones industrielles de Sindh, de Federal B et de Korangi à Karachi, où une pollution environnementale avait été anticipée. Les échantillons de sang des femmes enceintes $(n=416)$, de sang cordonal $(n=309)$ et de méconium ( $n=$ 309) ont fait l'objet d'une analyse quantitative à la recherche de métaux et d'éléments traces. Les résultats ont indiqué que les mères résidant dans des villes sidérurgiques présentaient les taux de plomb les plus élevés. Le méconium contenait des concentrations élevées de métaux lourds toxiques et d'éléments traces par rapport au sang cordonal et au sang maternel. Les métaux toxiques contenus dans le sang maternel étaient présents en grandes quantités. Par conséquent, des mesures de sécurité devraient être prises lorsque les déchets industriels sont éliminés afin de prévenir la contamination de la population.

'Dow University of Health Science, Dow Medical College, Karachi, Pakistan (Correspondence to: Sina Aziz: sigma_98@hotmail.com). ${ }^{2}$ International Center for Chemical and Biological Sciences, University of Karachi, Karachi, Pakistan. ${ }^{3}$ Abbasi Shaheed Hospital, Karachi Medical Dental College, Karachi, Pakistan.

Received: 27/03/16; accepted 23/01/17 


\section{Introduction}

Toxic metals are found in excess in industrial waste (1). Individuals living in industrial areas or in the vicinity of industrial areas are exposed to trace elements and heavy metals. This results in an adverse effect on their health and life in general (2-6). Pregnant women exposed to these metals and elements are at greater risk as both the fetus and mother will be affected $(1,2)$.

Various studies have been done to determine toxic metals and trace elements in the blood of individuals (3). Animal studies indicate toxic levels of lead in the gestational rat and its pup (4). However, few studies have been done to determine the levels of toxic metals in pregnant women and the new-born (5). Toxic levels of lead occur in children either due to their exposure to high levels of lead in the maternal blood or from the environment in which they are born. Most crucial time in children when they are prone to toxicity is the first two years of life (6). However, some heavy metals, e.g. lead, may be toxic to a child during the growth period, the effects of which may be seen in adulthood. High levels of lead may be due to air emissions, house dust, soil, water and consumer products (7). Similarly other heavy and light metals and trace elements can also be toxic to humans (8). Pakistan is a low socioeconomic country with the majority of the population residing in industrial cities such as Karachi, with an estimated population of over 23.5 million (9), and exposure to toxic metals may be at the maximum due to industrial waste.

Studies have been done on the coastal areas of Karachi, which have shown toxic levels of metals, such as lead $(\mathrm{Pb})$, cadmium $(\mathrm{Cd})$, light metal aluminium (Al) and trace elements [Zinc $(\mathrm{Zn})$, Copper $(\mathrm{Cu})$, and Iron $(\mathrm{Fe})]$. Data on these toxic metals and trace elements is lacking from the industrial areas of Karachi, and no published data is available from Pakistan on the level of toxic metals and trace elements in the meconium of babies born to mothers residing in industrial areas of Karachi. Individuals residing in these areas are subjected to a high quantity of these toxic metals and with a deficiency or excess of trace elements. These individuals can have neuropsychological deficits that include cognitive and functional compromise in the affected individual. The abnormalities may be subtle in nature. Pregnant women residing in industrial areas may be subjected to even greater risk, due to dual involvement of both mother and fetus.

This is an important study as environmental pollution is a worldwide problem, especially so in the developing world, where proper precautions, rules and regulations for disposal of industrial waste may not be followed. Toxic metals such as lead have already been found in the blood of adults residing in the city of Karachi (3). However, this study is important as it emphasizes that the toxic metals may be present in the mother and the new-born. Thus, residing in industrial areas of Karachi indicate that the unborn child may also be exposed to the toxic metals.

This study aimed to determine the levels of toxic heavy metals [(lead $(\mathrm{Pb})$, cadmium $(\mathrm{Cd})$ ], light metal aluminium (Al) and trace elements [Zinc ( $\mathrm{Zn})$, Copper $(\mathrm{Cu})$ and Iron $(\mathrm{Fe})]$ in pregnant women residing in these areas and their new-born. Information on toxic metals and trace elements in maternal blood, cord blood and meconium of the new-born gives an estimate of the levels of toxic metals and a deficiency or excess of trace elements, if any, in the samples of the pregnant women and their new-born. The null Hypothesis proposed that toxic heavy metals and trace elements are normal in pregnant maternal blood, cord blood and meconium of the new-born from industrial zones of Karachi, whereas the alternate hypothesis was that toxic metals and light metal aluminium, and trace elements are deficient in pregnant maternal blood, cord blood and meconium of the new-born from industrial zones of Karachi.

\section{Methods}

This analytical cross-sectional study was conducted from November 2011 to October 2012 in mothers and their new-born at two obstetric units of tertiary care government hospitals in Karachi, serving pregnant women from low socio-economic classes and residing in industrial areas of Karachi. These industrial areas are the Sindh Industrial Trading Estate (S.I.T.E.) area, F.B. (Federal B) Industrial area and Korangi industrial area. A detailed performa with maternal information along with information of the new-born was recorded. Those patients residing near Sindh Industrial Trading Estate (S.I.T.E.) area, F.B. (Federal B) Industrial area and Korangi industrial area Karachi were included.

\section{Sampling technique}

Patients were selected from each hospital by simple random sampling. Patients coming to civil hospitals residing in industrial areas in Korangi, Shershah, and Sind Industrial Trading Estate were included. This was based on preliminary information collected from the patients by the investigators. The calculated sample size $(95 \% \mathrm{CI})$ and margin of error $(53 \% \pm 2.5)$ was 1531 pregnant women.

At Abbasi Shaheed hospital and Civil hospital, samples from the mother and cord blood were taken at the time of delivery of the baby. Only mothers residing in the industrial areas were included. Three samples were taken from each study subject $(6-8 \mathrm{ml}$ maternal blood sample, 6-8 $\mathrm{ml}$ of umbilical cord blood and first meconium passed by the respective mother's new-born) (Figure 1). The blood samples and meconium were transported to Industrial Analytical Centre (IAC) at Hussain Ebrahim Jamal (H.E.J.) Research Institute of Chemistry, Karachi. The blood samples 


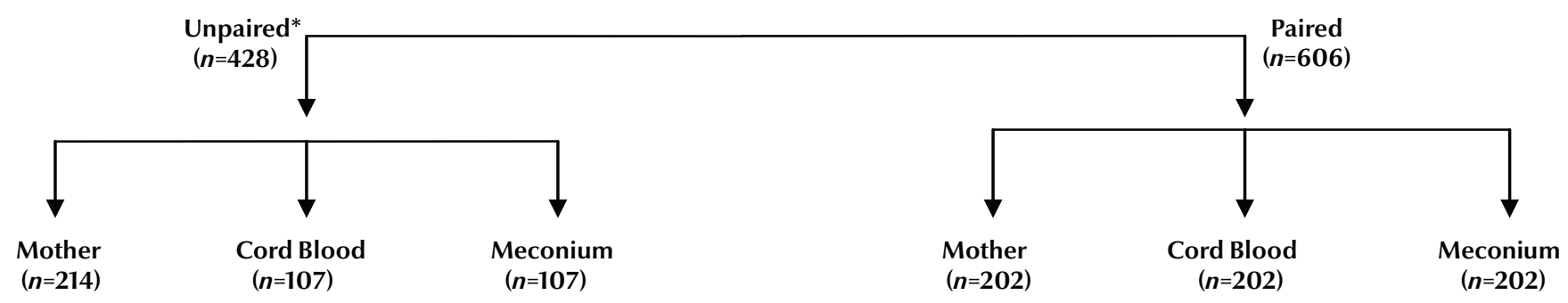

*Unpaired sample of maternal blood and cord blood or mother or meconium. Sample lost or mother left the postnatal ward without giving the meconium of her newborn.

Figure 1 Sample collected ( $\mathrm{N}=\mathrm{n1034}$ ) from pregnant women, cord blood and meconium of the new-born from Civil Hospital and Abbasi Shaheed Hospital, Karachi, Pakistan

were centrifuged and serum stored at $-86^{\circ} \mathrm{C}$ at IAC. Meconium obtained from each new-born's diaper, when first passed, was scraped into a sterile container and transferred along with remaining samples to IAC and stored at $-86^{\circ} \mathrm{C}$ temperature. Actual quantitative weight of meconium was also done at the laboratory. The average baby passes the meconium in first 24 to 48 hours of birth (10-12). Hence, the baby had to be followed carefully till the meconium was passed and collected in an appropriate container.

The toxic heavy metals [( Lead $(\mathrm{Pb})$, Cadmium (Cd)], light metal alumini$\operatorname{um}(\mathrm{Al})$ and trace elements $[\mathrm{Zinc}(\mathrm{Zn})$, Copper $(\mathrm{Cu})$ and Iron $(\mathrm{Fe})]$ in the blood of the mother, cord blood and the meconium of the new-born were determined. Methodology for the initial preparation of meconium for analysis was problematic as it is a thick viscous material (10,13). Quantitative analysis of heavy metals was done by flame atomic absorption spectrophotometer for meconium, at IAC, including the quantitative analysis performed by Inductive Coupled Plasma-Optical Emission Technique (ICP-OES) (14-16).

\section{Ethical approval}

Pregnant women were informed of the nature of study and consent taken from them either by thumb impression or signature prior to sample collection. The written form contained information for the mother in 3 languages (English, Urdu and Sindhi). The mother was informed that all information given remained confidential and anonymous. Also if levels of toxic metals were high or the levels of trace elements were abnormal in the mother or the new-born, then the paediatrician and obstetrician would provide health education and treatment. If a mother refused to be involved in the study, she was excluded.

The quantitative and qualitative information about a sample was obtained from the light and a radiation emitted by the exited atoms and ions. The actual detection of light was carried out a using Charge Coupled Detector (CCD). The concentration of the elements could be extracted from the intensities of emission lines of the elements. This was accomplished by using plots of emission intensity vs. concentrations. Calibration curves were established by analysing solutions with known concentrations and obtaining their emission intensities for each element. A Perkin Elmer Optima 2000 DV equipped with WinLab 32 software and equipped with a Ryton Scott-type spray chamber was used.

Samples for the analysis were in aqueous form and were filtered.
Conductivity of the samples was within range i.e. $10000 \mu$ s. The elements in the blood and meconium samples were analysed by ICP-OES. Conditions of the ICP-OES 2000 DV for the analysis included a radio frequency ( $R F$ ) power at $1300 \mathrm{~W}$, nebulizer flow at $0.8 \mathrm{~L} / \mathrm{min}$, auxiliary flow at $0.2 \mathrm{~L} / \mathrm{min}$, plasma flow of $20 \mathrm{~L} / \mathrm{min}$, pump flow of $0.8 \mathrm{~mL} /$ min, plasma viewing was dual view, torch position at -2.5 and sensitivity of $0.001 \mathrm{ppm}$. The values obtained of the metals analysed in the study samples were based on the reference values in published articles $(8,15,17,18)$, as shown in the Table 1.

All the followingvalues are expressed in (ppm). For toxic metals Lead (Pb) minimal and maximal detectable limits were $0.1-16.3,0.1-12$, and 0.2-65.4, for maternal blood, cord blood and meconium respectively. For cadmium (Cd) minimal and maximal detectable limits were in the range $0.1-8.5,0.1-3.2$ and 0.3-122.2 for maternal blood, cord blood and meconium respectively. While in case of aluminium ( $\mathrm{Al}$ ) minimal and maximal detectable limits were $0.1-358.8,0.1-385.2$ and $0.1-465.3$ respectively.

In trace element Zinc ( $\mathrm{Zn})$ minimal and maximal detectable limits were $0.1-529,0.25-251.25$ and $0.36-538.4$ for maternal blood, cord blood and 


\begin{tabular}{|c|c|c|}
\hline \multicolumn{3}{|c|}{$\begin{array}{l}\text { Table } 1 \text { Normal range of metals }(\mathrm{Cd}, \mathrm{Pb}, \mathrm{Zn}, \mathrm{Cu}) \text { in maternal and cord blood } \\
(20,21,22,23)\end{array}$} \\
\hline & Maternal blood (ppm) & Cord blood (ppm) \\
\hline \multicolumn{3}{|c|}{ Heavy toxic metals } \\
\hline $\mathrm{Cd}$ & 0.00089 & 0.00032 \\
\hline \multirow[t]{2}{*}{$\mathrm{Pb}$} & 0.0088 & 0.0097 \\
\hline & \multicolumn{2}{|c|}{ Trace elements } \\
\hline $\mathrm{Cu}$ & $1.003 \pm 0.159$ & 0.0951 \\
\hline $\mathrm{Zn}$ & $0.883 \pm 0.070$ & 4.738 \\
\hline *Fe & $1.272 \pm 0.340$ & \\
\hline
\end{tabular}

*Fe in normal female blood 0.3-1.6 ppm.

meconium respectively. In case of copper $(\mathrm{Cu})$ minimal and maximal detectable limits were $0.12-18.6,0.1-18$ and 0.4-193.7 for maternal blood, cord blood and meconium respectively. For Iron $(\mathrm{Fe})$ minimal and maximal detectable limits were $0.1-529,0.3-251.3$ and $0.4-538.4$ for maternal blood, cord blood and meconium respectively.

\section{Statistical analysis}

We applied Pearson's correlation test in our analysis to see the relationship between the three parameters, i.e. maternal blood, cord blood and meconium.
However, there was no significant relationship, so this analysis was not included. SPSS 17.0 for Windows (SPSS, Inc., Chicago, IL, USA) and Microsoft ${ }^{\circ}$ Office Excel $^{\circ} 2007$ (12.04518.1014) for Windows 7 Professional was used to perform statistical analysis. Values were expressed as (mean \pm standard deviation) and (max--min). To see the relationship among the variables, Karl Pearson's correlation technique was used. The significance of the difference among mean values was calculated using one-way ANOVA. Multiple comparison technique used was Scheffee and included location (residence of the mothers) for each element - lead $(\mathrm{Pb})$, cadmium $(\mathrm{Cd})$, aluminium $(\mathrm{Al})$, zinc $(\mathrm{Zn})$, copper $(\mathrm{Cu})$, and iron $(\mathrm{Fe})$ - between the three groups (meconium, cord blood and maternal

\begin{tabular}{|c|c|c|c|c|}
\hline \multicolumn{5}{|c|}{$\begin{array}{l}\text { Table } 2 \text { Descriptive statistics of zinc present in maternal blood }(n=416) \text {, cord blood }(n=309) \text { and meconium }(n=309) \text { of } \\
\text { different Karachi areas }\end{array}$} \\
\hline Location & $\begin{array}{l}\text { Maternal } \\
\text { blood } \\
(n=416) \\
\text { Mean } \pm \text { SD }\end{array}$ & $\begin{array}{l}\text { Cord blood } \\
\quad(n=309) \\
\text { Mean } \pm \text { SD }\end{array}$ & $\begin{array}{l}\text { Meconium } \\
(n=309) \\
\text { Mean } \pm \text { SD }\end{array}$ & $P$ \\
\hline Baldia Town & $3.6 \pm 4.6$ & $6 \pm 12$ & $80.7 \pm 148.2$ & 0.7132 \\
\hline Gadap Town & $4.7 \pm 11.7$ & $6.4 \pm 10.7$ & $78.4 \pm 117.4$ & 0.9698 \\
\hline Gulbarg Town & $4.3 \pm 10.4$ & $9.1 \pm 26.5$ & $75.7 \pm 119.7$ & $0.025 \wedge$ \\
\hline Gulshan-e-Iqbal Town & $9.6 \pm 15.5$ & $1.7 \pm 1.8$ & $25.3 \pm 21.5$ & 0.2391 \\
\hline Hyderabad & $268.1 \pm 369$ & $49.5 \pm 41.1$ & $43.1 \pm 18.7$ & 0.5583 \\
\hline Jamshed Town & $1.4 \pm 2.4$ & $1.5 \pm 1.7$ & $21.8 \pm 33.4$ & 0.388 \\
\hline Khairpur Town & $0 \pm 0$ & $0 \pm 0$ & $0 \pm 0$ & - \\
\hline Korangi Town & $17.4 \pm 12$ & $18.2 \pm 18.6$ & $35.3 \pm 40.8$ & 0.3864 \\
\hline Landhi Town & $10.5 \pm 12.3$ & $10.6 \pm 8.0$ & $18.2 \pm 18.1$ & 0.4316 \\
\hline Liaquatabad Town & $12.3 \pm 26.9$ & $8.0 \pm 12.8$ & $38.6 \pm 57.7$ & $0.0018 \wedge$ \\
\hline Lyari Town & $17 \pm 14.9$ & $24.7 \pm 20.8$ & $18.8 \pm 28.4$ & 0.7256 \\
\hline Malir town & $6.6 \pm 6.1$ & $33.6 \pm 58.6$ & $75.7 \pm 1508$ & 0.2105 \\
\hline New Karachi Town & $7.8 \pm 12.7$ & $15.3 \pm 14.9$ & $160.3 \pm 218.4$ & 0.1421 \\
\hline North Nazimabad & $11.3 \pm 17.3$ & $23.3 \pm 51.8$ & $35.1 \pm 95.5$ & 0.2323 \\
\hline Not Mentioned & $17.3 \pm 4.7$ & $7.4 \pm 6.1$ & $49.5 \pm 40.3$ & 0.0776 \\
\hline Orangi Town & $23.2 \pm 37.4$ & $24 \pm 35$ & $30.5 \pm 57.8$ & 0.8115 \\
\hline Saddar Town & $3.9 \pm 0$ & $0 \pm 0$ & $30.8 \pm 0$ & $<0.0001 \wedge$ \\
\hline Shah Faisal Town & $15.8 \pm 23.1$ & $9.2 \pm 11$ & $58.7 \pm 152.2$ & 0.2801 \\
\hline Site Town & $24.7 \pm 9.4$ & $23.8 \pm 12$ & $9.5 \pm 7.8$ & 0.3592 \\
\hline
\end{tabular}

Levels higher than the normal are indicated by: maternal blood ppm, Zn=0.883 \pm 0.070 and cord blood ppm, Zn=4.738 (20,21) while in meconium $>100 \mu / g$ dry wt was toxic (13).

$\wedge$ P-value shows that in Gulbarg town, Liaquatabad town, Saddar and Steel Town are significantly different by location. P-value indicates that the observed result would be highly unlikely under the null hypothesis. No detectable zinc was present in samples from Khairpur. 


\begin{tabular}{|c|c|c|c|c|}
\hline Location & $\begin{array}{c}\text { Maternal blood } \\
(n=416) \\
\text { Mean } \pm \text { SD }\end{array}$ & $\begin{array}{c}\text { Cord blood (ppm) } \\
(n=309) \\
\text { Mean } \pm \text { SD }\end{array}$ & $\begin{array}{c}\text { Meconium (ppm) } \\
(n=309) \\
\text { Mean } \pm \text { SD }\end{array}$ & $P$ \\
\hline Baldia Town & $0.1 \pm 0.3$ & $0.4 \pm 0.8$ & $4.9 \pm 8.3$ & 0.197 \\
\hline Gadap Town & $0.1 \pm 0.1$ & $0.4 \pm 0.6$ & $13.6 \pm 11.8$ & 0.0848 \\
\hline Gulbarg Town & $1.2 \pm 2.4$ & $1.5 \pm 2.7$ & $9.4 \pm 10.9$ & $<0.0001 \wedge$ \\
\hline Gulshan-e-Iqbal Town & $0.2 \pm 0.2$ & $0.1 \pm 0.1$ & $11.6 \pm 15.0$ & 0.2484 \\
\hline Hyderabad & $1.2 \pm 1.7$ & $0 \pm 0$ & $7 \pm 10.0$ & 0.5161 \\
\hline Jamshed Town & $0 \pm 0$ & $0.1 \pm 0.2$ & $2.2 \pm 3.9$ & 0.4423 \\
\hline Khairpur Town & $0 \pm 0$ & $0 \pm 0$ & $0 \pm 0$ & - \\
\hline Korangi Town & $2.1 \pm 4.4$ & $3.2 \pm 4.6$ & $7.7 \pm 7.5$ & 0.1696 \\
\hline Landhi Town & $0.5 \pm 0.7$ & $0.1 \pm 0.2$ & $2.3 \pm 6.0$ & 0.5638 \\
\hline Liaquatabad Town & $1.2 \pm 2.7$ & $1.3 \pm 2.8$ & $6.5 \pm 7.9$ & $<0.0001 \wedge$ \\
\hline Lyari Town & $0.1 \pm 0.4$ & $0 \pm 0$ & $10.0 \pm 9.4$ & $0.0002 \wedge$ \\
\hline Malir town & $4.1 \pm 5.3$ & $0.3 \pm 0.6$ & $9.3 \pm 10.5$ & $0.0139 \wedge$ \\
\hline New Karachi Town & $2.4 \pm 3.1$ & $0.6 \pm 0.4$ & $3.4 \pm 7.3$ & 0.634 \\
\hline North Nazimabad & $1.3 \pm 3.3$ & $0.7 \pm 2.0$ & $7.2 \pm 9.8$ & $<0.0001 \wedge$ \\
\hline Not Mentioned & $6.1 \pm 7.7$ & $2.0 \pm 1.7$ & $0 \pm 0$ & 0.2115 \\
\hline Orangi Town & $1.2 \pm 3.0$ & $0.7 \pm 2.4$ & $11.0 \pm 21.4$ & $0.0053 \wedge$ \\
\hline Saddar Town & $1.6 \pm 0$ & $0.3 \pm 0$ & $1.2 \pm 0$ & $<0.0001 \wedge$ \\
\hline Shah Faisal Town & $3.1 \pm 4.9$ & $2.6 \pm 4.5$ & $14.4 \pm 16.9$ & $0.0102 \wedge$ \\
\hline Site Town & $0 \pm 0$ & $0 \pm 0$ & $9.3 \pm 1.6$ & $0.003 \wedge$ \\
\hline
\end{tabular}

Pb levels higher than the normal: maternal blood ppm, $P b=0.0088$ and cord blood ppm, $P b=0.0097(20,2)$ while in meconium $>12 \pm 14.9 \mu / g$ dry wt was toxic $(24)$. $\wedge$ P-value shows that in Gulbarg town, Khairpur town, Liaquatabad town, Lyari, Malir, North Nazimabad, Orangi town, Saddar, Shah Faisal, Site town and Steel Town are significantly different by location. P-value indicates that the observed result would be highly unlikely under the null hypothesis.

blood). $P$-value $<0.05$ was considered statistically significant. Descriptive statistics were calculated for birth outcome characteristics and for toxic metals and trace elements.

\section{Results}

A total of 1034 samples were collected (meconium, maternal blood and cord blood). Of these, 606 were paired samples (meconium $n=202$, cord blood $n=202$, and maternal blood $n=202$ ). The remaining 428 were unpaired (maternal blood $n=214$, meconium $n=107$ and cord blood $n=107)$. The unpaired samples were either due to the mother leaving the hospital before the baby passed meconium or the sample of meconium was misplaced by the mother or thrown away; this was an expected mishap, despite counselling the mother repeatedly (Figure 1). In the paired samples $(n=606)$ response rate was $100 \%$ of participants, with mother $(n=202)$, cord blood $(n=202)$ and meconium $(n=202)$. In the unpaired group $(n=428)$ response rate was $66.7 \%$, with mother $(n=214)$, cord blood $(n=107)$ and meconium $(n=$ 107). Overall response rate was $83 \%$.

The results of 1034 samples of cord blood, maternal blood and meconium are shown in Tables 2-7. The meconium contained higher quantities of $\mathrm{Pb}$, $\mathrm{Cd}, \mathrm{Al}, \mathrm{Cu}, \mathrm{Fe}$ and $\mathrm{Zn}$ compared to cord blood and maternal blood, while $\mathrm{Pb}$ was present in cord blood in small amounts.

All the samples of meconium tested positive for toxic metals. Quantitative results (mean \pm SD) and frequency (\%) of towns with results of the metals in maternal blood, cord blood and meconium with respect to area of residence are shown in Tables 2-8. Of all residential areas, the steel mill area showed the highest levels of toxic metals, especially lead. The reference values have been mentioned in the legend for maternal blood, cord blood and meconium for each toxic metal and trace element mentioned in the tables.

Lead (Table 3 and Table 8): It was clearly shown that a large amount of lead was seen in the meconium in the new-born from all areas except Steel Town. Overall, in all areas where cord blood was studied, the amount of lead was very little or absent. In maternal blood the maximum amount of lead was seen in those mothers residing in Steel Town, Sadder Town and New Karachi Town. Overall, the number of towns with levels greater than 0.0088 (maternal blood) (14), 0.00032 (cord blood) (14) and meconium $12 \pm 14.9$ (18) was $11 / 20$, i.e. $55 \%$ in each sample tested. 


\begin{tabular}{|c|c|c|c|c|}
\hline Location & $\begin{array}{c}\text { Maternal blood } \\
\begin{array}{c}(n=416) \\
\text { Mean } \pm \text { SD }\end{array}\end{array}$ & $\begin{array}{c}\text { Cord Blood (ppm) } \\
\begin{array}{c}(n=309) \\
\text { Mean } \pm \text { SD }\end{array}\end{array}$ & $\begin{array}{c}\text { Meconium }(\mathrm{ppm}) \\
(n=309) \\
\text { Mean } \pm \text { SD }\end{array}$ & $P$ \\
\hline Baldia Town & $7.2 \pm 4.1$ & $14 \pm 20.1$ & $11.7 \pm 14$ & 0.7132 \\
\hline Gadap Town & $20.3 \pm 18.4$ & $18.4 \pm 16.7$ & $16.9 \pm 15.2$ & 0.9698 \\
\hline Gulbarg Town & $10.3 \pm 13.4$ & $19.2 \pm 26$ & $38 \pm 61.9$ & $0.025 \wedge$ \\
\hline Gulshan-e-Iqbal Town & $9.6 \pm 15.5$ & $1.7 \pm 1.8$ & $25.3 \pm 21.5$ & 0.2391 \\
\hline Hyderabad & $268.1 \pm 369$ & $49.5 \pm 41.1$ & $43.1 \pm 18.7$ & 0.5583 \\
\hline Jamshed Town & $1.4 \pm 2.4$ & $1.5 \pm 1.7$ & $21.8 \pm 33.4$ & 0.388 \\
\hline Khairpur Town & $0 \pm 0$ & $0 \pm 0$ & $0 \pm 0$ & - \\
\hline Korangi Town & $17.4 \pm 12$ & $18.2 \pm 18.6$ & $35.3 \pm 40.8$ & 0.3864 \\
\hline Landhi Town & $10.5 \pm 12.3$ & $10.6 \pm 8.0$ & $18.2 \pm 18.1$ & 0.4316 \\
\hline Liaquatabad Town & $12.3 \pm 26.9$ & $8.0 \pm 12.8$ & $38.6 \pm 57.7$ & $0.0025 \wedge$ \\
\hline Lyari Town & $17.0 \pm 14.9$ & $24.7 \pm 20.8$ & $18.8 \pm 28.4$ & 0.7256 \\
\hline Malir town & $6.6 \pm 6.1$ & $33.6 \pm 58.6$ & $75.7 \pm 150.8$ & 0.2105 \\
\hline New Karachi Town & $7.8 \pm 12.7$ & $15.3 \pm 14.9$ & $160.3 \pm 218.4$ & 0.1421 \\
\hline North Nazimabad & $11.3 \pm 17.3$ & $23.3 \pm 51.8$ & $35.1 \pm 95.5$ & 0.2323 \\
\hline Not Mentioned & $17.3 \pm 4.7$ & $7.4 \pm 6.1$ & $49.5 \pm 40.3$ & 0.0776 \\
\hline Orangi Town & $23.2 \pm 37.4$ & $24 \pm 35$ & $30.5 \pm 57.8$ & 0.8115 \\
\hline Saddar Town & $3.9 \pm 0$ & $0 \pm 0$ & $30.8 \pm 0$ & $<0.0001 \wedge$ \\
\hline Shah Faisal Town & $15.8 \pm 23.1$ & $9.2 \pm 11$ & $58.7 \pm 152.2$ & 0.2801 \\
\hline Site Town & $24.7 \pm 9.4$ & $23.8 \pm 12$ & $9.5 \pm 7.8$ & 0.3592 \\
\hline Steel Town & $0 \pm 0$ & $0 \pm 0$ & $109 \pm 0$ & $<0.0001 \wedge$ \\
\hline
\end{tabular}

Levels higher than the normal were indicated by: maternal blood ppm, Fe=1.272 \pm 0.0340 (21), while in meconium $>100 \mu / g$ dry wt was toxic (13).

$\wedge$-value shows that in Gulbarg town, Khairpur town, Liaquatabad town, Saddar and Steel Town are significantly different by location wise. P-value indicates that the observed result would be highly unlikely under the null hypothesis. In Khairpur, Sadder and Steel Town Fe was not detected.

Cadmium (Table 6 and Table 8): It was seen that Site Town and Baldia Town were highly affected, i.e. cadmium was present in the cord blood, followed by Jamshed Town and New Karachi, which were somewhat less affected. Meconium contained high quantities of cadmium in Landhi, Malir, Shah Faisal, Lyari, Gadap and Liaquatabad Town. In Hyderabad, maternal blood contained cadmium, while surprisingly it was absent in the cord blood and meconium of the new-born. Overall, the percentage of towns with level greater than 0.0089 (maternal blood) (14), 0.00032 (cord blood) (14) and meconium $3.0 \pm 7.44$ (4) was $20 \%, 5 \%$ and $20 \%$ respectively, in each sample tested.

Zinc (Table 2 and Table 8): Zinc was present in large amount in the meconium in all areas except Hyderabad. In Steel Town area, zinc was absent in maternal blood and cord blood. In Korangi, Landhi, Lyari, Malir, North Nazimabad, Orangi and Site Town areas, zinc was present in the same amount both in cord blood and maternal blood. Overall, the percentage of towns with level greater than 0.883 \pm 0.070 (maternal blood) (15), 4.738 (cord blood) (14) and meconium $>100 \mu \mathrm{g} / \mathrm{g}(8)$ was $90 \%, 75 \%$ and $55 \%$ respectively, in each sample tested.

Iron (Table 4 and Table 8): Significant amount of iron was present in the meconium of the new-born from all the areas included in the study. However, the maximum amount of iron was seen in the meconium of the Steel Town area. In maternal blood and cord blood, the amount of iron was very little, except in Hyderabad area where the maternal blood contained significant amount of iron. Overall, percentage of towns with levels greater than $1.272 \pm 0.340$ (maternal blood) (15), and meconium $>100 \mu \mathrm{g} / \mathrm{g}(8)$ were $90 \%$ and $20 \%$ respectively.

Copper (Table 5 and Table 8): Copper was present in the meconium in all areas except Site Town, Khairpur Town and Gulshan-e-Iqbal Areas, where copper was not detected in the meconium. Overall, in cord blood the amount of copper present was negligible. Copper was detected in all the samples of maternal blood with the maximum being from those residing in Gulshan-e-Iqbal area. Overall, percentage of towns with copper levels greater than $1.003 \pm 0.159$ (mother's blood) (15), 0.0951 (cord blood) (14) was $80 \%$ and $70 \%$ respectively, and in meconium (8) copper values $>100 \mu \mathrm{g} / \mathrm{g}$ were not detected. 


\begin{tabular}{|c|c|c|c|c|}
\hline Location & $\begin{array}{c}\text { Maternal blood } \\
\begin{array}{c}(n=416) \\
\text { Mean } \pm \text { SD }\end{array}\end{array}$ & $\begin{array}{l}\text { Cord blood }(\mathrm{ppm}) \\
\qquad \begin{array}{c}(n=309) \\
\text { Mean } \pm \text { SD }\end{array}\end{array}$ & $\begin{array}{c}\text { Meconium }(\mathrm{ppm}) \\
(n=309) \\
\text { Mean } \pm \text { SD }\end{array}$ & $P$ \\
\hline Baldia Town & $1.2 \pm 0.5$ & $1.7 \pm 2.8$ & $5.1 \pm 5.6$ & 0.1633 \\
\hline Gadap Town & $3.8 \pm 5.5$ & $1 \pm 1.5$ & $2.1 \pm 3.7$ & 0.7026 \\
\hline Gulbarg Town & $2.3 \pm 2.7$ & $1.4 \pm 2.4$ & $5.6 \pm 8.8$ & $0.0106 \wedge$ \\
\hline Gulshan-e-lqbal Town & $3.8 \pm 2.1$ & $0.9 \pm 1.1$ & $0 \pm 0$ & $0.0328 \wedge$ \\
\hline Hyderabad & $6 \pm 5.8$ & $3.5 \pm 4.2$ & $28.7 \pm 33$ & 0.4602 \\
\hline Jamshed Town & $0.7 \pm 0.6$ & $0 \pm 0.1$ & $1.6 \pm 2.8$ & 0.5411 \\
\hline Khairpur Town & $0 \pm 0$ & $0 \pm 0$ & $0 \pm 0$ & ----- \\
\hline Korangi Town & $6.2 \pm 6.0$ & $5.2 \pm 3.8$ & $26.3 \pm 39.2$ & 0.1825 \\
\hline Landhi Town & $1.7 \pm 1.7$ & $5.9 \pm 8.7$ & $4.9 \pm 5.4$ & 0.4074 \\
\hline Liaquatabad Town & $2.7 \pm 2.3$ & $1.5 \pm 2.4$ & $8.4 \pm 15.3$ & $0.0067 \wedge$ \\
\hline Lyari Town & $6.6 \pm 4.6$ & $2.8 \pm 3.7$ & $3.9 \pm 7.0$ & 0.2566 \\
\hline Malir town & $2.7 \pm 2.9$ & $4.3 \pm 5.8$ & $10.4 \pm 23.3$ & 0.3758 \\
\hline New Karachi Town & $4.5 \pm 7.7$ & $1.8 \pm 2.6$ & $5.8 \pm 6.0$ & 0.5491 \\
\hline North Nazimabad & $2.3 \pm 2.9$ & $1.5 \pm 2.4$ & $5.3 \pm 12.4$ & $0.0488 \wedge$ \\
\hline Not Mentioned & $5.6 \pm 2.9$ & $2.6 \pm 2.9$ & $19.7 \pm 23.2$ & 0.2199 \\
\hline Orangi Town & $2.7 \pm 3.0$ & $1.7 \pm 3.1$ & $16.4 \pm 41$ & 0.0522 \\
\hline Saddar Town & $1.6 \pm 0$ & $0.5 \pm 0$ & $5 \pm 0$ & $<0.0001 \wedge$ \\
\hline Site Town & $7 \pm 0.3$ & $8.7 \pm 5.4$ & $0 \pm 0$ & 0.1298 \\
\hline Steel Town & $0.8 \pm 0$ & $0.1 \pm 0$ & $13.9 \pm 0$ & $<0.0001 \wedge$ \\
\hline
\end{tabular}

Levels were higher than the normal are indicated by: maternal blood ppm, Cu=1.003 \pm 0.159 and cord blood ppm, Cu=0.0951 (20,21) while in meconium >100 $\mu / g$ dry wt was toxic (13).

^P-value shows that in Gulbarg town, Gulshan-e-Iqbal Town, Khairpur town, Liaquatabad town, North Nazimabad, Saddar and Steel Town are significantly different by location. P-value indicates that the observed result would be highly unlikely under the null hypothesis.

Table 6 Descriptive statistics of cadmium present in maternal blood $(n=416)$, cord blood $(n=309)$ and meconium $(n=309)$ for different Karachi areas

\begin{tabular}{|c|c|c|c|c|}
\hline Location & $\begin{array}{l}\text { Maternal blood } \\
\quad(n=416) \\
\text { Mean } \pm \text { SD }\end{array}$ & $\begin{array}{c}\text { Cord blood }(\mathrm{ppm}) \\
(\mathbf{n}=309) \\
\text { Mean } \pm \text { SD }\end{array}$ & $\begin{array}{c}\text { Meconium }(\mathrm{ppm}) \\
(\mathrm{n}=309) \\
\text { Mean } \pm \text { SD }\end{array}$ & $\mathbf{P}$ \\
\hline Baldia Town & $0 \pm 0.1$ & $0.6 \pm 1.3$ & $0 \pm 0$ & 0.3587 \\
\hline Gadap Town & $0 \pm 0$ & $0 \pm 0.1$ & $0.7 \pm 0.7$ & 0.1435 \\
\hline Gulbarg Town & $0 \pm 0.1$ & $0.1 \pm 0.3$ & $0.3 \pm 0.7$ & $0.0317 \wedge$ \\
\hline Gulshan-e-lqbal Town & $0 \pm 0$ & $0 \pm 0$ & $0 \pm 0$ & - \\
\hline Hyderabad & $0 \pm 0$ & $0 \pm 0$ & $0 \pm 0$ & - \\
\hline Jamshed Town & $0 \pm 0$ & $0 \pm 0$ & $0 \pm 0$ & - \\
\hline Khairpur Town & $0 \pm 0$ & $0 \pm 0$ & $0 \pm 0$ & - \\
\hline Korangi Town & $1.2 \pm 3.2$ & $0 \pm 0$ & $3.4 \pm 8.1$ & 0.2059 \\
\hline Landhi Town & $0 \pm 0$ & $0 \pm 0.1$ & $1.9 \pm 5$ & 0.4562 \\
\hline Liaquatabad Town & $0 \pm 0.1$ & $0.1 \pm 0.2$ & $1.3 \pm 4.9$ & 0.1359 \\
\hline Lyari Town & $0 \pm 0$ & $0 \pm 0$ & $4.3 \pm 9.8$ & 0.1571 \\
\hline Malir town & $0 \pm 0$ & $0 \pm 0.1$ & $0.6 \pm 1.1$ & 0.0832 \\
\hline New Karachi Town & $0.1 \pm 0.1$ & $0.1 \pm 0.2$ & $0 \pm 0$ & 0.1633 \\
\hline North Nazimabad & $0.1 \pm 0.3$ & $0 \pm 0$ & $0.1 \pm 0.4$ & 0.2034 \\
\hline Not Mentioned & $0.3 \pm 0.5$ & $0.6 \pm 0.9$ & $6.6 \pm 13.4$ & 0.4511 \\
\hline Orangi Town & $0 \pm 0$ & $0 \pm 0.1$ & $0.1 \pm 0.4$ & 0.1747 \\
\hline Saddar Town & $0.1 \pm 0$ & $0.1 \pm 0$ & $1.7 \pm 0$ & $<0.0001 \wedge$ \\
\hline Shah Faisal Town & $0 \pm 0.1$ & $0 \pm 0.1$ & $8.1 \pm 31.6$ & 0.3909 \\
\hline Site Town & $0 \pm 0$ & $0.1 \pm 0.1$ & $0 \pm 0$ & 0.4648 \\
\hline Steel Town & $0 \pm 0$ & $0 \pm 0$ & $0 \pm 0$ & - \\
\hline
\end{tabular}

Level higher than the normal Cd levels: maternal blood ppm, Cd=0.00089 and cord blood ppm, Cd=0.00032 (20,21) while in meconium >3 $\pm .44 \mu / g$ dry wt was toxic (24).

$\wedge$ P-value shows that in Gulbarg town, Khairpur town, Saddar and Steel Town are significantly different by location. P-value indicates that the observed result would be highly unlikely under the null hypothesis. 


\begin{tabular}{|c|c|c|c|c|}
\hline Location & $\begin{array}{c}\text { Maternal blood } \\
(n=416) \\
\text { Mean } \pm \text { SD }\end{array}$ & $\begin{array}{c}\text { Cord blood }(\mathrm{ppm}) \\
(n=309) \\
\text { Mean } \pm \text { SD }\end{array}$ & $\begin{array}{c}\text { Meconium }(\mathrm{ppm}) \\
(n=309) \\
\text { Mean } \pm \text { SD }\end{array}$ & $P$ \\
\hline Baldia Town & $11.4 \pm 19.3$ & $18.8 \pm 25$ & $95.6 \pm 84$ & 0.0776 \\
\hline Gadap Town & $23.2 \pm 27.4$ & $36.9 \pm 8$ & $144.2 \pm 98.4$ & 0.0872 \\
\hline Gulbarg Town & $11.8 \pm 12.5$ & $20.8 \pm 27.6$ & $141.2 \pm 119.2$ & $<0.0001 \wedge$ \\
\hline Gulshan-e-lqbal Town & $120.7 \pm 206.2$ & $7.3 \pm 7.5$ & $190.6 \pm 147.1$ & 0.3646 \\
\hline Hyderabad & $38.2 \pm 32.5$ & $3.8 \pm 1.0$ & $218.1 \pm 42.3$ & $0.0115 \wedge$ \\
\hline Jamshed Town & $0.7 \pm 1.2$ & $0.8 \pm 0.8$ & $81.8 \pm 115.7$ & 0.3019 \\
\hline Khairpur Town & $0 \pm 0$ & $0 \pm 0$ & $0 \pm 0$ & - \\
\hline Korangi Town & $8.1 \pm 7$ & $6.1 \pm 5.4$ & $84.6 \pm 65$ & $0.0013 \wedge$ \\
\hline Landhi Town & $13.5 \pm 17$ & $12 \pm 15.4$ & $130.1 \pm 97.2$ & $0.0036 \wedge$ \\
\hline Liaquatabad Town & $5.3 \pm 8.7$ & $6.5 \pm 8.8$ & $109.9 \pm 94.7$ & $<0.0001 \wedge$ \\
\hline Lyari Town & $7.7 \pm 10.9$ & $13.4 \pm 13.2$ & $45.5 \pm 64.6$ & 0.0723 \\
\hline Malir town & $13.8 \pm 20.5$ & $32.1 \pm 63$ & $119 \pm 95.2$ & $0.0012 \wedge$ \\
\hline New Karachi Town & $15.8 \pm 21.8$ & $20.4 \pm 32.8$ & $193.1 \pm 113.7$ & $0.0022 \wedge$ \\
\hline North Nazimabad & $9.3 \pm 17.9$ & $31.9 \pm 81.5$ & $146.3 \pm 121.2$ & $<0.0001 \wedge$ \\
\hline Not mentioned & $22.5 \pm 20.7$ & $8.1 \pm 10.4$ & $86.6 \pm 42.8$ & $0.0076 \wedge$ \\
\hline Orangi Town & $16.4 \pm 22.6$ & $25.8 \pm 32.7$ & $102.9 \pm 101.4$ & $<0.0001 \wedge$ \\
\hline Saddar Town & $6.2 \pm 0$ & $4.6 \pm 0$ & $210.7 \pm 0$ & $<0.0001 \wedge$ \\
\hline Shah Faisal Town & $12.9 \pm 19.4$ & $9.0 \pm 13.6$ & $141.6 \pm 125.2$ & $<0.0001 \wedge$ \\
\hline Site Town & $1.6 \pm 2.3$ & $11.0 \pm 10.4$ & $218.3 \pm 97.5$ & 0.0513 \\
\hline Steel Town & $0.2 \pm 0$ & $0 \pm 0$ & $11.3 \pm 0$ & $<0.0001 \wedge$ \\
\hline
\end{tabular}

$\wedge$ P-value shown for Gulbarg town, HyderabadKhairpur town, Korangi, Landhi, Liaquatabad,Malir, New Karachi, North Nazimabad, Others, Orangi, Saddar, Shah Faisal town and Steel Town are significantly different by location. P-value indicates that the observed result would be highly unlikely under the null hypothesis.

Aluminium (Table 7 and Table 8): Aluminium was present in meconium in all areas studied. However, the concentration of aluminium was low in maternal blood in Jamshed Town, Khairpur town, Saddar Town, Site Town and Steel Town Areas. Reference values for aluminium could not be found in the biological samples analysed.

\section{Discussion}

The objective of our project was to determine toxic metal levels and trace elements in maternal blood, cord blood and meconium of the new-born. The levels identified will inform medical workers, industrialists and environmentalists about the toxic effects and levels of these metals and trace elements in pregnant women and their new-born.
This project can have an influence on the social sector and indirectly on the economy. The human fetus, child and adult may experience adverse health outcomes from parental or childhood exposures to environmental toxicants. The fetus and infant are especially vulnerable to toxicants that disrupt developmental processes during the limited period of pregnancy. The adverse health effects linked to exposure of toxic metals - e.g. lead and cadmium and trace elements such as zinc, copper and iron - include fetal death, birth defects, Small for Gestational age (SGA), pre-term birth, clinically overt cognitive, neurologic and behavioural abnormalities, subtle neurophysiologic defects, childhood cancer, asthma, and other respiratory diseases. Environmental toxicants, especially lead, produce adverse effects at low exposure levels during fetal or developmental time periods (7).
Limited numbers of studies have been conducted on specific exposure during pregnancy.

Although sample analysis of metals such as lead has been undertaken previously $(3-5,8,19)$, this is the first study done on pregnant mothers and their new-born via cord blood and meconium. Animal studies have already been undertaken (5) where the effects of lead intoxication during pregnancy and lactation was studied in the hepatic system of rats, which indicated adverse neonatal liver function. Based on this study and previous studies $(3-5,8,19)$, we expected high levels of lead in the samples of maternal blood, cord blood and meconium from industrial areas of Karachi. In this study the presence of lead in the fetus occurred due to the free passage of lead from the mother to the fetus, which is of clinical relevance since 


\begin{tabular}{|c|c|c|c|}
\hline & Maternal blood (\%) & Cord blood (\%) & Meconium (\%) \\
\hline \multicolumn{4}{|l|}{ Trace elements } \\
\hline Zinc (Zn) & 90 & 75 & 55 \\
\hline Copper (Cu) & 80 & 70 & $100^{*}$ \\
\hline Iron (Fe) & 90 & Not detected & 20 \\
\hline \multicolumn{4}{|l|}{ Toxic metals } \\
\hline Lead $(\mathrm{Pb})$ & 55 & 55 & 55 \\
\hline Cadmium (Cd) & 20 & 25 & 20 \\
\hline Aluminium (Al) & \multicolumn{3}{|c|}{ Comparative published data not available } \\
\hline
\end{tabular}

Frequency (\%) of industrial towns having trace elements and toxic metals in the maternal blood, cord blood and meconium of the new-born are shown. In meconium, levels $>700 \mu \mathrm{g} / \mathrm{g}$ are toxic.

* $100 \%$ of the meconium samples did not contain Cu levels in toxic amounts. Al levels have not been documented previously in a research studies. For the remaining, reference values are used $(8,15)$.

lead is always toxic, irrespective of its concentration (20).

Few studies have been conducted on cadmium levels. When we compared our results with previous studies $(8,14)$, we found the levels to be higher in pregnant women and the cord blood of the study group. Presence of these toxic metals in the meconium may indicate the excretion of the metals by the baby in utero. Hence, the meconium passed by the baby after birth contains a high quantity of the metals.

All our meconium samples tested positive for toxic metals and trace elements. Meconium reflects fetal exposure to toxic metals and mineral content, from mother to the fetus via blood circulation and excessive levels of toxins and certain toxic metals which harm the fetus. The levels of toxic metals and trace elements in cord blood may not reflect the extent of fetal exposure to toxic metals or the actual degree of excess or deficiency of trace elements. The reason is that the substances processed by the fetus accumulate in the fetal intestine, thus meconium analysis can be used to assess levels of fetal exposure to toxic metals and mineral content and indirectly of the mother and the environment in which she and her family resides. This may explain the higher quantities of lead, cadmium, copper, iron and zinc in the meconium of the new-born than in the cord blood and maternal blood $(8,14,15)$.

In this study the percentage of zinc and iron in meconium $>100 \mu \mathrm{g} / \mathrm{g}$ dry weight was seen in $55 \%$ and $20 \%$ of the industrial towns of Karachi; the study conducted by Türker et al. (8) showed $90 \%$ and $53 \%$ respectively, possibly due to the population studied which was in very close proximity (within a 20 $\mathrm{km}$ radius) of the petroleum refinery and dye industries. While $100 \%$ of the meconium samples tested for copper $<100 \mu \mathrm{g} / \mathrm{g}$, in the Türker study $100 \%$ of the samples tested $>100 \mu \mathrm{g} / \mathrm{g}$. This variation could be due to interference with the rates of placental transport of trace element. This observation needs further research as some of the minerals, e.g. zinc, are transported across the placenta against a concentration gradients (21).

This study, on the other hand, has shown higher levels when compared to previous studies done by Cibele et al. (14) on toxic and essential elements in maternal and cord blood. Certain industrial areas, e.g. S.I.T.E and Steel town area, showed much higher levels. Iron levels were low compared to international data, due to micronutrient deficiency in the mothers and hence in the new-born and even the meconium. Overall, this indicates iron deficiency in women in the area, which is supported by other studies from the region (22).
Comments on aluminium could not be made since this is the first time maternal, cord and meconium samples have been collected for analysis. However, this analysis may give an insight as a standard for further studies, especially from low socio-economic areas. This study included only pregnant women residing in industrial areas. Therefore, further work should be done with a larger sample size to include individuals not residing in the industrial areas in order to avoid bias.

A limitation of this study is that environmental assessment of the studied elements and its correlation with blood levels was not done. This aspect needs to be covered in future studies.

Broad longitudinal studies beginning before or during early pregnancy are urgently needed to accurately measure and assess the relative importance of parental and childhood exposure in order to evaluate adverse effects such as neurophysiologic and other functional defects. There is also an urgent need to accelerate development and use of biomarkers of exposures and genetic susceptibility in epidemiological studies.

It is recommended that a larger sample size study be done involving the complete family residing in the industrial areas; knowledge of exact distance from the industrial site; analysis 
of placental samples; and father and/ or mother working in the concerned industry as an inclusion criterion. Also, it needs to be determined whether or not industries are using the recommended safety environmental precautions, which should also be critically assessed, as well as government measures taken for the safety of individuals and their families residing at or near the industrial towns.
Funding: Pakistan Science Foundation (PSF No. S-DUHS/MED 290)

Competing interests: None declared.

\section{References}

1. larushkin Vlu. Tiazhelye metally v biologicheskoř sisteme mat'-novorozhdennyı̌ v usloviiakh tekhnogennol biogeokhimicheskol provintsii (in Russian).Gig Sanit. 1992 May-Jun;5-6(5-6):13-5. PMID:1398163

2. Odland JO, Romanova N, Sand G, Thomassen Y, Brox J, Khotova $\mathrm{E}$, et al. Preliminary report of trace elements in mothers and newborns living in the Kola Peninsula and Arkhangelsk region of Russia compared to Norwegian populations. Arctic Med Res. 1996;55 Suppl 1:38-46. PMID:8871686

3. Agha F, Sadaruddin A, Khatoon N. Effect of environmental lead pollution on blood lead levels in traffic police constables in Islamabad, Pakistan. J Pak Med Assoc. 2005 Oct;55(10):410-3. PMID:16304845

4. Corpas I, Benito MJ, Marquina D, Castillo M, Lopez N, Antonio MT. Gestational and lactational lead intoxication produces alterations in the hepatic system of rat pups. Ecotoxicol Environ Saf. 2002 Jan;51(1):35-43. http://dx.doi.org/10.1006/ eesa.2001.2102 PMID:11800548

5. Privalova LI, Malykh OL, Matiukhina GV, Gnezdilova SV. [The umbilical blood levels of lead and some other toxic metals as a biomarker of environment-induced exposure]. Gig Sanit. 2007 May-Jun;3(3):68-70. PMID:17658049

6. Braun JM, Lanphear B, Schoeters G, Hanke W, Rennezova Z, et al. Comments on 'Lead neurotoxicity in children: is prenatal exposure more important than postnatal exposure?'. Acta Paediatr. 2007 Mar;96(3):473, author reply 474-5. http://dx.doi. org/10.1111/j.1651-2227.2007.00131.x PMID:17407486

7. Berkowitz Z, Price-Green P, Bove FJ, Kaye WE. Lead exposure and birth outcomes in five communities in Shoshone County, Idaho. Int J Hyg Environ Health. 2006 Mar;209(2):123-32. http://dx.doi.org/10.1016/j.ijheh.2005.11.001 PMID:16376613

8. Türker G, Ergen K, Karakoç Y, Arisoy AE, Barutcu UB. Concentrations of toxic metals and trace elements in the meconium of newborns from an industrial city. Biol Neonate. 2006;89(4):244-50. http://dx.doi.org/10.1159/000089953 PMID:16319451

9. Aziz S, Leroy P, Servaes R, Eggermont E, FeveryJ. Bilirubin-IXbeta is a marker of meconium, like zinc coproporphyrin. J Pediatr Gastroenterol Nutr. 2001 Mar;32(3):287-92. http://dx.doi. org/10.1097/00005176-200103000-00010 PMID:11345177

10. Aziz S, Kotal P, Leroy P, Servaes R, Eggermont E, Fevery J. Bilirubin-IXalpha and -IXbeta pigments, coproporphyrins and bile acids in meconium and stools from full-term and preterm neonates during the first month of life. Acta Paediatr. 2001 Jan;90(1):81-7. http://dx.doi.org/10.1111/j.1651-2227.2001. tb00260.x PMID:11227340

11. Aziz. S. Nature of bilirubin pigments in the newborn infant Ti JdschrKindergeeneskd 1996; 64: 3

12. Aziz S. On the nature of the bilirubin pigments in the newborn infant. ActaBiomedicaLovaniensia 114. KatholiekeUniversitei- tte Leuven. Faculteit der Geneeskunde. LaboratriumvoorHepatologie. AfdelingKindergeenskunde. Leuven: Leuven University press; 1995.

13. Aziz S, Anjum S, Rehman A, Akram DS, Naqvi A, Rizvi AH. Bilirubin pigments in the first meconium of newborn infants JPMA 2005; 55: 188-92 Erratum in. J Pak Med Assoc. 2005;55:313.

14. Rudge CV, Röllin HB, Nogueira CM, Thomassen $Y$, Rudge MC, Odland JØ. The placenta as a barrier for toxic and essential elements in paired maternal and cord blood samples of South African delivering women. J Environ Monit. 2009 Jul;11(7):1322-30. http://dx.doi.org/10.1039/b903805a PMID:20449220

15. Selvaraju R, Raman RG, Narayanaswami R, Valliappan R. Trace element analysis in hepatitis B affected human blood serum by inductively coupled plasma- atomic emission spectroscopy (ICP-AES) Romanian J. Biophys., Vol 19, No. 1, P. 35-42, Bucharest, 2009.

16. Wu Alan HB. Tietz Guide to laboratory tests. 4th ed. Philadelphia: WB Saunders; 2006

17. Engorn B. Flerlage Blood Chemistries and Body Fluids. The Johns Hopkins Hospital. The Harriet Lane Handbook. 20th ed. Philadelphia: Saunders; 2015. pp. 621-33.

18. Optima 8300 ICP-OES Spectrometer. (http://www.perkinelmer.com/catalog/product/id/optima8300 accessed 31 December 2015).

19. Benes B, Spěvácková V, Smíd J, Cejchanová M, Cerná M, Subrt $\mathrm{P}$, et al. The concentration levels of $\mathrm{Cd}, \mathrm{Pb}, \mathrm{Hg}, \mathrm{Cu}, \mathrm{Zn}$ and $\mathrm{Se}$ in blood of the population in the Czech Republic. Cent Eur J Public Health. 2000 May;8(2):117-9. PMID:10857051

20. Nashashibi N, Cardamakis E, Bolbos G, Tzingounis V. Investigation of kinetic of lead during pregnancy and lactation. Gynecol Obstet Invest. 1999;48(3):158-62. http://dx.doi. org/10.1159/000010164 PMID:10545737

21. Page KR, Abramovich DR, Aggett PJ, Todd A, Dacke CG. The transfer of zinc across the term dually perfused human placental lobule. Q J Exp Physiol. 1988 Jul;73(4):585-93. http:// dx.doi.org/10.1113/expphysiol.1988.sp003178 PMID:3174917

22. Ahmed A, Ahmad A, Khalid N, David A, Sandhu MA, Randhawa MA, et al. A question mark on iron deficiency in 185 million people of Pakistan: its outcomes and prevention. Crit Rev Food Sci Nutr. 2014;54(12):1617-35. http://dx.doi.org/10.1080 /10408398.2011.645087 PMID:24580562

23. Whitehall JS, Ostrea EM, Bollistety S, Whitehall JF, Patole S. Fetal exposure to pollutant in Towsville, Australia detected in meconium. Pediatr Res. 2000;47:299A.

24. Ostrea EM Jr, Tan E, Ramirez G, Hernandez E, Manlapaz ML. Exposure to environmental pollution adversely affects fatal outcome. Pediatr Res. 1998;43:224A. 